\title{
PENGARUH KUALITAS PRODUK DAN HARGA TERHADAP MINAT KONSUMEN PADA INDUSTRI KRIPIK TEMPE "MAHKOTA" DI DESA PRANDON KABUPATEN NGAWI
}

\author{
Rumanita Rohmawati \\ Mahasiswa Prodi Ekonomi FPIPS IKIP PGRI MADIUN
}

\begin{abstract}
Abstrak: Tujuan dari penelitian ini adalah mengetahui Kualitas Produk Industri Kripik Tempe "Mahkota" di Prandon, Ngawi untuk mengetahui harga kripik tempe "Mahkota" di Prandon, Ngawi. Untuk mengetahui minat Konsumen terhadap kripik tempe "Mahkota" di Prandon, Ngawi juga untuk mengetahui ada pengaruh atau tidak Kualitas Produk dan harga terhadap minat konsumen pada industri kripik tempe "Mahkota" di Prandon, Ngawi. Sampel dalam penelitian ini adalah sampel insidental dari siapa saja yang memiliki kesempatan yang memenuhi peneliti adalah 50 konsumen yang membeli kripik Tempe "Mahkota" di Paron, Ngawi. Pengumpulan data yang digunakan adalah metode kuisioner dan dokumentasi. Analisis dalam penelitian ini menggunakan metode statistik uji regresi product moment. Kualitas produk dan Harga memiliki berhubungan dan berpengaruh positif pada industri kripik tempe "Mahkota" di Prandon, Ngawi. Hal ini diperoleh dari uji korelasi yang menunjukkan besarnya nilai korelasi. Besarnya nilai $\mathrm{r}_{\text {hitung }} 0,471$ sedangkan $\mathrm{r}_{\text {tabel }} 0,279$ selain itu nilai $\operatorname{Sig}_{\text {hit }}$ adalah 0,003 , sedangkan $\operatorname{Sig}_{\text {prob }}$ adalah 0,005 . Hal ini berarti bahwa nilai $\mathrm{r}_{\text {hitung }} \geq$ $r_{\text {tabel }}(0,471 \geq 0,279)$ atau $\operatorname{Sig}_{\text {hit }} \leq \operatorname{Sig}_{\text {prob }}(0,003 \leq 0,005) r_{\text {hitung }}$ adalah 0,471 . Ini berarti ada $H_{0}$ ditolak yang menunjukkan kualitas produk dan harga, memiliki hubungan positif dengan daya tarik konsumen pada industri kripik tempe "Mahkota" di Prandon, Ngawi. Hasil uji $\mathrm{R}_{2}$ adalah 0,22 sedangkan $77,8 \%$ sisanya akan terpengaruh dengan faktor lain. Setelah itu diperoleh hasil uji fisher. Nilai $F_{\text {hitung }}$ adalah 6.693. $F_{\text {tabel }}$ adalah 4,043. Di samping itu bahwa besarnya $\operatorname{Sig}_{\text {hit }}$ adalah 0,003 sedangkan $\operatorname{Sig}_{\text {prob }}$ 0,05. Itu berarti bahwa nilai $\mathrm{F}_{\text {hitung }} \geq \mathrm{F}_{\text {tabel }}(6.693$ $\geq 4.043)$ atau $\operatorname{Sig}_{\text {hit }} \leq \operatorname{Sig}_{\text {prob }}(0003 \leq 0,05)$. Ini berarti $\mathrm{H}_{0}$ kualitas produk dan harga memiliki pengaruh untuk membandingkan pelanggan pada industri kripik tempe "Mahkota" di Prandon, Ngawi. Selain itu, adalah diperoleh dari persamaan garis regresi $Y=14,271+$ $0,401 X_{1}+0,196 X_{2}$. Di samping itu diperoleh dari uji t yang nilai $t_{\text {hitung }}$ adalah 3,195 dan $t_{\text {tabel }}$ adalah 1,677. Nilai $\operatorname{Sig}_{\text {hit }}$ adalah $0,002 \operatorname{dan}_{\operatorname{Sig}_{\text {prob }}} 0,05$. Ini berarti bahwa nilai $t_{\text {hitung }} \geq t_{\text {tabel }}(3,195$ $\geq 1,677)$ atau $\operatorname{Sig}_{\text {hit }} \leq \operatorname{Sig}_{\text {prob }}(0,002 \leq 0,05)$. Ini berarti ada kualitas penolakan $H_{0}$. Produk memiliki pengaruh yang berbeda untuk daya tarik konsumen pada industri kripik tempe "Mahkota" di Prandon, Ngawi. Nilai $t_{\text {hitung }}$ adalah 1,631 sedangkan $t_{\text {tabel }}$ adalah 1.677. Selain itu, nilai $\operatorname{Sig}_{\text {hit }}$ adalah 0.110 sedangkan $\operatorname{Sig}_{\text {prob }}$ 0,05. Ini berarti bahwa nilai $\mathrm{t}_{\text {hitung }} \leq \mathrm{t}_{\text {tabel }}(1631 \leq$ $1,677)$ atau $\operatorname{Sig}_{\text {hit }} \geq \operatorname{Sig}_{\text {prob }}(0110 \geq 0,05)$. Itu berarti ada suatu $H_{0}$ penerimaan. Harga tidak memiliki pengaruh yang berbeda untuk daya tarik konsumen pada industri kripik tempe "Mahkota" di Prandon, Ngawi.
\end{abstract}

Kata Kunci: Kualitas Produk, dan Harga, Minat Konsumen. 


\section{PENDAHULUAN}

Dalam sebuah industri, keberadaan industri kecil merupakan kunci penentu dalam kemampuan daya saing industri. Secara keseleluruhan konsep, rencana, dan umpan balik yang diperoleh industri kecil akan ditransformasikan ke dalam industri. Industri kecil merupakan elemen dari industri yang menerjemahkan seluruh kebutuhan manajemen agar dapat menjawab permintaan pasar.

Industri kripik tempe "Mahkota" bergerak di bidang industri rumahan (home industri) yang menghasilkan produk kripik tempe berbagai kemasan, dari kemasan kecil, sedang, dan besar, dari kemasan itu harganya juga berbeda. Banyak para konsumen yang membeli untuk dijadikan oleh-oleh dan produk ini biasanya disetor di toko-toko di sekitar Kabupaten Ngawi. Untuk memperoleh suatu produk yang berkualitas industri pertama harus memiliki bahan baku yang baik dan terjamin kualitasnya agar produk yang dihasilkan bisa menjadi produk yang mempunyai harga jual yang banyak diminati konsumen. Agar para konsumen lebih meminati produk yang dihasilkan maka harga dan produk yang dijual harus memiliki tingkat produk yang berkualitas serta daya ketahanan produk yang ada bisa terjamin agar tidak cepat rusak untuk dikonsumsi. Di dalam industri kripik tempe "Mahkota" harga dan kuliatas produk apakah akan berpengaruh terhadap minat konsumen untuk membelinya. Kualitas produk kripik tempe di industri "Mahkota" sangat dibutuhkan karena jika dari kualitas produknya tidak terjamin maka minat konsumen juga berpengaruh. Salah satu upaya agar kualitas produk tetap terjaga maka dari segi kemasan produk harus memiliki tempat yang tidak mudah mlempem agar tetap terasa rasanya. Dengan adanya kualitas produk dan harga apakah akan mempengaruhi minat konsumen untuk membeli olahan kripik tempe.

Menurut Geotch dan Davis (dalam Fandy dan Anastasia 2000:4) menyatakan bahwa Kualitas adalah suatu kondisi yang dinamis yang berhubungan dengan produk, jasa, manusia, orang, proses dan lingkungan yang memenuhi dan melebihi apa yang diharapkan oleh para konsumen.

Menurut J.M. Juran (dalam Fandy Tjiptono dan Anastasia 2000:24) aspek kualitas sebagai berikut: 1). Ciri-ciri produk yang memenuhi permintaan pelanggan, 2). bebas dari kekurangan, dari pernyataan tersebut dapat dijelaskan bahwa:

1. Ciri-ciri produk yang memenuhi permintaan pelanggan

Kualitas yang lebih tinggi memungkinkan perusahaan meningkatkan kepuasan pelanggan, membuat produk laku terjual, dapat meningkatkan harga yang lebih efisien bersaing dengan pesaing meningkatkan pangsa pasar, serta dapat dijual dengan harga yang lebih tinggi.

2. Bebas dari kekurangan

Kualitas yang tinggi menyebabkan perusahaan dapat mengurangi tingkat kesalahan, mengurangi pengerjaan kembali dan pemborosan, mengurangi biaya garansi, mengurangi ketidakpuasan pelanggan, mengurangi waktu pengiriman produk ke pasar, meningkatkan hasil (yield) dan kapasitas, dan memperbaiki kinerja penyampaian produk atau jasa.

\section{Klasifikasi Produk}

Menurut Thamrin dan Francis (2012: 155-159) menyatakan bahwa klasifikasi produk sebagai berikut:

1. Produk Konsumen

Produk yang dibeli konsumen ahir untuk konsumen dan untuk konsumen pribadi. Produk konsumen dibagi beberapa produk yaitu:

a. Produk sehari-hari : produk atau jasa konsumen yang pembeliannya sering, dan seketika.

b. Produk shopping : produk konsumen yang lebih jarang dibeli, sehingga pelanggan membandingkan dengan cermat kesesuaian, mutu, hara, dan gayanya. 
2. Produk industri

Barang yang dibeli untuk diproses lebih lanjut untuk dipergunakan untuk menjalankan bisnis. Produk industri ada tiga kelompok yaitu:

a. Bahan dan suku cadang Produk industri yang menjadi bagian produk pembeli, lewat pengolahan lebih lanjut atau sebagai komponen.

b. Barang modal Industri yang membantu produksi atau operasi pembeli, yang termasuk barang yang dibangun dan peralatan tambahan.

c. Perlengkapan dan jasa Produk industri yang sama sekali yang tidak memasuki produk ahir.

\section{Mutu produk}

Mutu adalah suatu alat penting bagi pemasar untuk mendapatkan posisi. Mutu mempunyai dua dimensi, yaitu tingkat dan konsistensi. Ketika mengembangkan produk, pemasar mula-mula harus memilih tingkat mutu yang akan mendukung posisi produk di pasar sasaran.

\section{Sifat-sifat produk}

Alat bersaing untuk membedakan produk perusahaan dari produk pesaing. Cara lain yang menambah nilai bagi pelanggan lewat rancangan produk yang akan membedakan produk perusahaan dan produk pesaing.

5. Rancangan produk

Cara untuk menambah nilai bagi pelanggan, adalah lewat rancangan produk yang membedakan. Beberapa perusahaan yang mempunyai reputasi untuk rancangan yang amat mencolok.

\section{Harga}

Harga merupakan penentu utama dalam melakukan penjualan suatu produk, konsumen maupun pembeli barang maupun jasa selalu memperhatikan harga. Jika produk berkualitas maka harga juga akan mempengaruhi jual beli produk. Untuk menetapkan tingkat harga tersebut biasanya dilakukan dengan mengadakan percobaan untuk menguji.
Menurut Husein Umar (2000:32) menyatakan bahwa harga adalah nilai yang ditukarkan konsumen dengan manfaat dari memiliki atau menggunakan produk atau jasa yang nilainya ditetapkan oleh pembeli dan penjual melalui tawar menawar, atau ditetapkan oleh penjual untuk satu harga yang sama terhadap semua pembeli.

\section{Faktor-faktor yang Mempengaruhi Tingkat Harga}

Basu Swasta dan Irawan (2005:242) menyatakan faktor-faktor harga berikut: 1). Keadaan perekonomian, 2). Penawaran dan permintaan, 3). Elasitas permintaan, 4). Persaingan, 5). Biaya, 6). Tujuan perusahaan, 7). Pengawasan pemerintah dari pernyataan tersebut dapat dijelaskan bahwa faktor yang mempengaruhi harga sebagai berikut:

1. Keadaan perekonomian

Keadaan perekonomian sangat mempengaruhi tingkat harga yang berlaku.

2. Penawaran dan permintaan

Sejumlah barang yang dibeli oleh pembeli pada tingkat harga tertentu. Pada umumnya tingkat harga yang lebih rendah akan mengakibatkan jumlah yang diminta lebih besar.

3. Elastisitas permintaan

Faktor yang mempengaruhi penentuan harga adalah sifat permintaan pasar, sebenarnya sifat permintaan pasar ini tidak hanya mempengaruhi penentuan harga tetapi juga mempengaruhi volume yang dapat dijual.

4. Persaingan

Harga jual beberapa macam barang sering dipengaruhi oleh keadaan persaingan yang ada, dalam persaingan penjual yang berjumlah banyak aktif menghadapi pembeli yang banyak juga.

5. Biaya

Biaya merupakan dasar dalam penentuan harga, sebab suatu tingkat harga yang tidak dapat menutup biaya akan mengakibatkan kerugian, sebaliknya apabila suatu tingkat 
harga melebihi suatu biaya, baik biaya produksi, biaya operasi maupun biaya non operasi, akan menghasilkan keuntungan.

6. Tujuan perusahaan

Penetapan harga suatu barang sering dikaitkan dengan tujuan-tujuan yang akan dicapai, setiap perusahaan tidak selalu mempunyai tujuan yang sama dengan perusahaan lain.

7. Pengawasan pemerintah

Merupakan faktor yang paling penting dalam menentukan harga, pengawasan pemerintah dapat berwujud harga maksimum dan harga minimum.

\section{Perilaku Konsumen}

Konsumen juga memainkan peranan penting dalam kebijakan publik, dengan mengetahui perilaku konsumen dapat memanfaatkan untuk kepentingan pengembangan kemampuan seseorang pemasar dalam menjalankan tugasnya. Industri untuk menjual produk-produk yang dihasilkan jika berkualitas sehingga akan diminati banyak konsumen akan merasa puas jika ia membeli produk yang berkualitas dan puas untuk dikonsumsi.

Menurut Philip Kotler dan Gary (2008:158) menyatakan bahwa perilaku konsumen adalah pembelian konsumen ahir perorangan maupun rumah tangga yang membeli barang dan jasa untuk konsumsi sehari-hari bagi kebutuhan pribadi.

\section{Minat Konsumen}

Konsumen membuat banyak keputusan pembeli setiap hari, sehingga produk yang konsumen beli hampir setiap hari konsumen mengkonsumsi produk-produk yang dibeli. Konsumen untuk membeli produk pun menginginkan produl-produk yang berkualitas, jadi industri yang menghasilkan produk yang diinginkan konsumen harus berkualitas. Konsumen mempunyai peranan penting dalam memilih suatu produk yang berkualitas dan produk yang kurang berkulitas sehingga keinginan konsumen untuk membeli produk sangat tertarik.
Sementara itu menurut Simamora (2002:131) minat adalah sesuatu yang pribadi dan berhubungan dengan sikap, individu yang berminat terhadap suatu obyek akan mempunyai kekuatan atau dorongan untuk melakukan serangkaian tingkah laku untuk mendekati atau mendapatkan objek tersebut.

\section{Faktor-faktor yang Mempengaruhi Perilaku Konsumen}

Menurut Philip Kotler dan Gary Armstrong (2008:159) faktor-faktor yang mempengaruhi perilaku konsumen sebagai berikut: 1). Faktor kebudayaan, 2). Faktor sosial, 3). Faktor pribadi, 4). Faktor psikologis. Dari pernyataan tersebut dapat dijelaskan sebagai berikut:

1. Faktor kebudayaan

Faktor budaya mempunyai pengaruh yang luas dan mendalam pada perilaku konsumen, pemasar harus memahami peran yang dimainkan oleh budaya, sub budaya, peranan dari faktor budaya.

2. Faktor sosial

Perilaku konsumen juga dipengaruhi oleh faktor-faktor sosial seperti kelompok kecil, keluarga, serta peran dan status sosial konsumen. Faktor sosial mempunyai peranan yaitu : Kelompok tua atau lebih orang yang berinteraksi untuk mencapai tujuan pribadi atau tujuan bersama.

3. Faktor pribadi

Keputusan pembeli dipengaruhi oleh karakteristik pribadi seperti usia dan tahap siklus hidup pembeli, pekerjaan, situasi ekonomi, gaya hidup serta kepribadian dan konsep diri. Peranan dalam faktor pribadi yaitu : Usia dan tahap siklus hidup orang membeli barang dan jasa yang berbeda sepanjang hidup mereka, selera makanan, pakaian, perabot, dan rekreasi sering berhubungan dengan usia.

4. Faktor psikologis

Pilihan pembelian seseorang dipengaruhi oleh empat faktor psikologis utama motivasi, persepsi, pembelajaran, serta 
keyakinan, dan sikap. Faktor psikologis meliputi peranan yaitu: Motivasi: seseorang senantiasa mempunyai banyak kebutuhan, salah satunya kebutuhan biologis, dorongan tertentu seperti rasa lapar, haus serta ketidaknyamanan.

\section{Pengaruh Kualitas Produk dan Harga Terhadap Minat Konsumen}

Pemahaman konsumen dapat mempunyai dampak yang penting pada strategi harga. Secara umum, harga yang lebih tinggi, kurang mempunyai kemungkinan untuk dibeli oleh konsumen. Bagaimana pun beberapa kondisi, konsumen mempunyai hubungan harga dan kualitas. Dalam rentan harga tertentu untuk suatu produk, konsumen mungkin mempunyai ekspektasi harga yang lebih mahal mencerminkan kualitas suatu produk yang lebih baik yang mempunyai harga jual yang tinggi, dan mempunyai kualitas yang bagus agar para konsumen pun juga menginginkan produk yang akan dibeli serta merasa puas akan produk yang dibeli.

Menurut Nugroho J. Setiadi (2003:177) menyatakan bahwa Konsumen mempunyai beberapa keyakinan dan kepercayaan bahwa dalam situasi tertentu harga menunjukkan kualitas, terjadi perbedaan kualitas yang dirasakan atau yang sebenarnya di antara merek-merek yang ada. Perbedaan harga yang besar mempunyai dampak pada perbedaan kualitas yang dirasakan dari perbedaan yang lebih kecil, merek yang sangat dikenal, harga dapat digunakan secara lebih baik sebagai indikator kualitas.

\section{METODE PENELITIAN}

Tempat Penelitian dalam penelitian ini tempat penelitian dilaksanakan pada industri kripik tempe "Mahkota" di Desa Prandon Kabupaten Ngawi. Penelitian ini dilakukan selama 4 bulan, mulai bulan Februari 2013 sampai dengan bulan Mei 2013.

\section{Rancangan Penelitian}

Nasution (2004:23) menyatakan desain penelitian adalah rencana tentang cara mengumpulkan dan menganalisis data agar dapat dilaksanakan secara ekonomis dan serasi dengan tujuan penelitian itu.

Rancangan penelitian yang digunakan dalam penelitian ini adalah penelitian deskriptif. Menurut Hadari Nawawi (2005: 63) penelitian diskriptif adalah prosedur pemecahan masalah yang diselidiki dengan menggambarkan atau melukiskan keadaan subyek atau obyek penelitian (seseorang, lembaga, masyarakat dan lain-lain) pada saat sekarang berdasarkan fakta yang tampak atau sebagaimana adanya. Ciri-ciri penelitian deskriptif adalah memusatkan perhatian pada masalah-masalah yang ada pada saat penelitian dilakukan (saat sekarang) atau masalahmasalah yang bersifat aktual, menggambarkan fakta-fakta tentang masalah yang diselidiki sebagaimana adanya.

Rancangan penelitian ini dapat dilihat pada gambar 3.1 sebagai berikut:

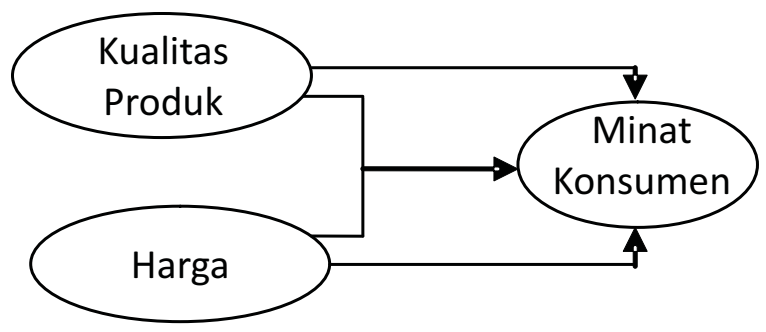

Dalam penelitian ini terdapat 3 variabel Variabel Bebas (variabel independent). Dalam penelitian ini variabel bebas $\mathrm{X}$ ada dua yaitu variabel $\left(\mathrm{X}_{1}\right)$ yaitu kualitas produk dan variabel $\left(\mathrm{X}_{2}\right)$ yaitu Harga. Variabel terikat (variabel dependent). Dalam penelitian ini yang menjadi variabel independent adalah variabel $(\mathrm{Y})$ minat konsumen.

\section{Populasi, Sampel, dan Teknik Peng- ambilan Sampel Populasi}

Dalam penelitian ini yang menjadi populasi adalah konsumen yang membeli kripik tempe di industri "Mahkota". Yang menjadi sampel adalah konsumen yang membeli kripik tempe di industri kripik tempe yaitu 50 konsumen. Teknik pengambilan 
sampel yang digunakan dalam penelitian adalah sampel insidental. Sugiyono (2010: 124) mengatakan sampel insidental adalah teknik penentuan sampel berdasarkan kebetulan, yaitu siapa saja yang secara kebetulan atau insidental bertemu dengan peneliti dapat digunakan sebagai sampel, bila dipandang orang yang kebetulan ditemui itu cocok sebagai sumber data.

Dalam penelitian ini teknik pengumpulan data yang digunakan adalah kuesioner. Kuosioner yang digunakan dalam penelitian ini berbentuk kuesioner tertutup artinya kuesioner tersebut sudah disediakan jawabannya sehingga responden tinggal memilih jawaban yang tersedia. Dalam penelitian ini kuesioner digunakan untuk mengetahui kualitas produk dan harga terhadap minat konsumen untuk membeli kripik tempe dengan menggunakan lembar kuesioner. Jumlah kuesioner adalah 27 butir soal untuk variabel X1, X2, dan Y yaitu minat konsumen.

\section{Analisis Data}

Analisis data menggunakan statistik. Menurut Gabriel Amin Silalahi (2003:82) Statistik mempunyai banyak pengertian di antaranya adalah sebagai kumpulan metode yang dapat digunakan untuk menarik kesimpulan yang masuk akal dari suatu data, untuk menganalisisnya menggunakan uji regresi linear berganda.

Regresi linear berganda adalah metode yang digunakan untuk melihat hubungan atau pengaruh dari dua atau tiga variabel (dan atau lebih) variabel independen terhadap satu variabel dependen. Moehar Daniel (2003: 156).

\section{HASIL PENELITIAN}

Deskripsi variabel kualitas produk dengan jumlah data (N) sebanyak 50 mempunyai deskripsi data sebagai berikut: (a) jumlah skor total sebesar 1827; (b) nilai rata-rata hitung (mean) sebesar 36,54; (c) median sebesar 36,00; (d) modus sebesar 36; (e) standar deviasi sebesar 3,092,486; (f) nilai minimum sebesar 28; (g) nilai maximum sebesar 43. Dari analisis diskriptif di atas dapat dikatakan bahwa kualitas produk pada industri kripik tempe "Mahkota" di Desa Pandon Kabupaten Ngawi, dikatakan baik karena dari 50 responden yang memperoleh nilai di atas rata-rata $\geq 36,54$ sebanyak 32 orang atau sebanyak 64\% mempunyai kualitas produk baik. Sedangkan sisanya yang 18 orang atau sebanyak 36\% mempunyai kualitas produk yang kurang baik.

Deskripsi variabel harga dengan jumlah data $(\mathrm{N})$ sebanyak 50 mempunyai deskripsi data sebagai berikut: (a) jumlah skor total sebesar 1815; (b) nilai rata-rata hitung (mean) sebesar 36,30; (c) median sebesar 36,00; (d) modus sebesar 36; (e) standar deviasi sebesar 3,221; (f) nilai minimum sebesar 27; (g) nilai maximum sebesar 42. Dari data deskriptif di atas dapat dikatakan bahwa harga pada industri kripik tempe "Mahkota" di Desa Prandon Kabupaten Ngawi, dikatakan baik karena dari 50 responden yang memperoleh nilai di atas rata-rata $\geq 36,30$ atau sebanyak 28 orang atau sebanyak 56\% mempunyai harga yang tinggi. Sedangkan sisanya yang 22 orang atau sebanyak $44 \%$ mempunyai harga rendah.

Deskripsi minat konsumen dengan jumlah data $(\mathrm{N})$ sebanyak 50 mempunyai deskripsi data sebagai berikut: (a) jumlah skor total sebesar 1803; (b) nilai rata-rata hitung (mean) sebesar 36,06; (c) median sebesar 36,50; (d) modus sebesar 37; (e) standar deviasi sebesar 3,013; (f) nilai minimum sebesar 27; (g) nilai maximum sebesar 42. Dari analisis deskripif di atas bahwa minat konsumen pada industri kripik tempe "Mahkota" di Desa Prandon Kabupaten Ngawi, dikatakan baik karena dari 50 responden yang memperoleh nilai di atas ratarata $\geq 36,06$ sebanyak 34 orang atau sebanyak $68 \%$ mempunyai minat yang baik. Sedangkan sisanya yang 16 orang atau sebanyak 32\% mempunyai minat kurang baik. 


\section{Pengujian Hipotesis}

Uji hipotesis dengan alat bantu program spss for windows 16.0 yang diperoleh hasil sebagai berikut:

Tabel 4.9. Hasil Uji Korelasi Model Summary

\begin{tabular}{|c|c|c|c|c|}
\hline Model & $\mathrm{R}$ & $\begin{array}{c}\mathrm{R} \\
\text { Square }\end{array}$ & $\begin{array}{c}\text { Adjusted } \\
\text { R Square }\end{array}$ & $\begin{array}{c}\text { Std. Error of } \\
\text { the Estimate }\end{array}$ \\
\hline 1 & $.471^{\mathrm{a}}$ & .222 & .189 & 2.714 \\
\hline
\end{tabular}

a. Predictors: (Constant), HARGA, KUALITAS_PRODUK

Berdasarkan tabel 4.9. di atas diketahui bahwa besarnya nilai $r_{\text {hitung }}$ adalah 0,471 sedangkan $r_{\text {tabel }}$ 0,279. Selain itu nilai $\mathrm{Sig}_{\text {hit }}$ 0,003 sedangkan $\operatorname{Sig}_{\text {prob }}$ 0,05. Hal ini berarti bahwa nilai $r_{\text {hitung }} \geq r_{\text {tabel }}(0,471 \geq 0,279)$ atau $\operatorname{Sig}_{\text {hit }} \leq \operatorname{Sig}_{\text {prob }}(0,003 \leq 0,05)$. Atas dasar uji korelasi tersebut dapat disimpulkan tolak $\mathrm{H}_{0}$, artinya ada hubungan kualitas produk dan harga terhadap minat konsumen pada industri kripik tempe "Mahkota" di Desa Prandon Kabupaten Ngawi.

Selain diperoleh nilai untuk korelasi $\mathrm{R}^{2}$ (R Square) atau koefisien determinasi yang digunakan untuk mengetahui seberapa besar prosentase sumbangan kualitas produk dan harga terhadap minat konsumen. Berdasarkan tabel 4.9. tersebut di atas dapat diketahui nilai $\mathrm{R}^{2}$ adalah 0,222 . Jadi sumbangan pengaruh dari kualitas produk dan harga terhadap minat konsumen yaitu $22,2 \%$. Sedangkan sisanya sebesar 77,8\% dipengaruhi oleh faktor lain.

Hasil uji anova diketahui bahwa besarnya nilai $\mathrm{F}_{\text {hitung }}$ adalah 6,693 sedangkan $\mathrm{F}_{\text {tabel }}$ sebesar 4,043, di lain pihak besarnya Sig $_{\text {hit }}$ adalah 0,003 sedangkan $\operatorname{Sig}_{\text {prob }}$ 0,05. Hal ini berarti bahwa nilai $F_{\text {hitung }} \geq F_{\text {tabel }}(6,693 \geq 4,043)$ atau $\operatorname{Sig}_{\text {hit }} \leq \operatorname{Sig}_{\text {prob }}(0,003 \leq 0,05)$. Atas dasar uji Fisher tersebut dapat disimpulkan tolak $\mathrm{H}_{0}$, artinya ada pengaruh kualitas produk dan harga terhadap minat konsumen pada industri kripik tempe "Mahkota" Desa Prandon Kabupaten Ngawi.
Selain digunakan untuk mencari pengaruh, uji Fisher atau Anova bisa juga digunakan untuk menguji linearitas. Karena $F_{\text {hitung }}$ sebesar 6,693 $\geq F_{\text {tabel }}$ sebesar 4,043, berarti ada hubungan yang linier antara variabel kualitas produk dan harga terhadap minat konsumen.

Atas dasar hasil Uji $\mathrm{t}$ dapat dibuat persamaan garis regresi linear berganda sebagai berikut $Y=14,271+0,401 \mathrm{X}_{1}+0,196$ $\mathrm{X}_{2}$.

Analisis tersebut dapat dijelaskan sebagai berikut :

$a=14,271$, artinya apabila variabel kualitas produk dan harga sama dengan nol sehingga minat konsumen tersebut sebesar 14,271.

$\mathrm{b}_{1}=0,401$ artinya nilai 0,401 merupakan koofisien regresi yang menunjukkan bahwa setiap upaya penambahan sebesar satu poin di kualitas produk akan ada kenaikan minat konsumen sebesar 0,401 .

$\mathrm{b}_{2}=0,196$ artinya nilai 0,196 merupakan koofisien regresi yang menunjukkan bahwa setiap upaya penambahan sebesar satu poin di harga akan ada kenaikan minat konsumen sebesar 0,196 .

\section{Simpulan Uji Korelasi}

Hasil dari pengujian korelasi dapat diperoleh besarnya nilai $r_{\text {hitung }}$ adalah 0,471 sedangkan $r_{\text {tabel }} 0,279$. Selain itu nilai $\mathrm{Sig}_{\text {hit }}$ 0,003 sedangkan $\mathrm{Sig}_{\text {prob }}$ 0,005. Hal ini berarti bahwa nilai $r_{\text {hitung }} \geq r_{\text {tabel }}(0,471 \geq$ $0,279)$ atau $\operatorname{Sig}_{\text {hit }} \leq \operatorname{Sig}_{\text {prob }}(0,003 \leq 0,005)$. $\mathrm{r}_{\text {hitung }}$ adalah 0,471. Selain itu, dalam penelitian ini diperoleh $\mathrm{R}^{2}$ adalah 0,222 . Hal ini menunjukkan bahwa sebanyak $22,2 \%$. Jadi sumbangan pengaruh dari kualitas produk dan harga terhadap minat konsumen yaitu $77,8 \%$. Sesuai hipotesis yang diajukan dapat diperoleh simpulan bahwa ada hubungan kualitas produk dan harga terhadap minat konsumen pada industri kripik tempe "Mahkota" di Desa 
Prandon Kabupaten Ngawi. Berarti $\mathrm{H}_{0}$ ditolak.

2. Simpulan Uji Fisher

Dari hasil analisis data yang telah dilakukan untuk uji fisher diperoleh bahwa nilai $\mathrm{F}_{\text {hitung }}$ adalah 6,693 sedangkan $\mathrm{F}_{\text {tabel }}$ sebesar 4,043, di lain pihak besarnya Sig $_{\text {hit }}$ adalah 0,003 sedangkan $\operatorname{Sig}_{\text {prob }} 0,05$. Hal ini berarti bahwa nilai $\mathrm{F}_{\text {hitung }} \geq \mathrm{F}_{\text {tabel }}(6,693 \geq 4,043)$ atau $\operatorname{Sig}_{\text {hit }} \leq \operatorname{Sig}_{\text {prob }}(0,003 \leq 0,05)$. Atas dasar uji Fisher tersebut dapat disimpulkan tolak $\mathrm{H}_{0}$, artinya ada pengaruh kualitas produk dan harga terhadap minat konsumen pada industri kripik tempe "Mahkota" Desa Prandon Kabupaten Ngawi.

3. Simpulan Ujit

Dari hasil analisis yang digunakan dalam uji t diperoleh persamaaan regresi sebagai berikut $Y=14,271+0,401 X_{1}+0,196 X_{2}$.

Selanjutnya dapat diketahui variabel kualitas produk mempunyai nilai $\mathrm{t}_{\text {hitung }}$ adalah 3,195 sedangkan $t_{\text {tabel }}$ sebesar 1,677, di lain pihak nilai $\mathrm{Sig}_{\text {hit }}$ adalah 0,002 sedangkan $\operatorname{Sig}_{\text {prob }} 0,05$. Hal ini berarti bahwa nilai $t_{\text {hitung }} \geq$ $\mathrm{t}_{\text {tabel }}(3,195 \geq 1,677)$ atau $\operatorname{Sig}_{\text {hit }} \leq \operatorname{Sig}_{\text {prob }}(0,002 \leq$ $0,05)$. Dapat disimpulkan tolak $\mathrm{H}_{0}$ artinya ada beda pengaruh kualitas produk terhadap minat konsumen pada industri kripik tempe "Mahkota" di Desa Prandon Kabupaten Ngawi.

Selain itu dapat diketahui variabel harga mempunyai nilai $t_{\text {hitung }}$ adalah 1,631 sedangkan $\mathrm{t}_{\text {tabel }}$ sebesar 1,677, di lain pihak nilai $\operatorname{Sig}_{\text {hit }}$ adalah 0,110 sedangkan $\operatorname{Sig}_{\text {prob }} 0,05$. Hal ini berarti bahwa nilai $t_{\text {hitung }} \geq t_{\text {tabel }}(1,631 \geq$ $1,677)$ atau $\operatorname{Sig}_{\text {hit }} \leq \operatorname{Sig}_{\text {prob }}(0,110 \leq 0,05)$. Dapat disimpulkan terima $\mathrm{H}_{0}$ artinya tidak ada beda pengaruh harga terhadap minat konsumen pada industri kripik tempe "Mahkota" di Desa Prandon Kabupaten Ngawi.

Daerah penolakan $\mathrm{H}_{0}$ pada uji $\mathrm{t}$ dalam penelitian ini variabel kualitas produk terhadap minat konsumen.

\section{PEMBAHASAN}

Hasil penelitian menunjukkan bahwa kualitas produk dan harga berpengaruh terhadap minat konsumen. Hal ini menunjukkan bahwa kualitas produk dan harga mempunyai keunggulan kualitas produk serta sesuai dengan harga yang ditawarkan oleh konsumen. Karena dalam suatu industri harus menghasilkan kualitas produk yang bagus dan sesuai dengan harga yang ditawarkan sehingga konsumen akan merasa puas akan produk yang dibeli.

Pembahasan untuk penelitian ini menggunakan uji regresi (uji korelasi, uji fisher, dan uji t) pembahasan untuk uji tersebut adalah sebagai berikut:

\section{Pembahasan Uji Korelasi}

Untuk uji korelasi diperoleh besarnya nilai $\mathrm{r}_{\text {hitung }}$ adalah 0,471 sedangkan $\mathrm{r}_{\text {tabel }} 0,279$. Selain itu nilai $\mathrm{Sig}_{\text {hit }}$ 0,003 sedangkan $\operatorname{Sig}_{\text {prob }} 0,05$. Hal ini berarti bahwa nilai $\mathrm{r}_{\text {hitung }}$ $\geq r_{\text {tabel }}(0,471 \geq 0,279)$ atau $\operatorname{Sig}_{\text {hit }} \leq \operatorname{Sig}_{\text {prob }}$ $(0,003 \leq 0,05) . r_{\text {hitung }}$ adalah 0,471 . Selain itu diperoleh nilai $\mathrm{R}^{2}$ adalah 0,222 . Hal ini menunjukkan bahwa sebanyak 22,2\% kualitas produk dan harga dipengaruhi oleh minat konsumen. Dengan hal ini $\mathrm{H}_{0}$ ditolak, artinya ada hubungan kualitas produk dan harga dengan minat konsumen pada industri kripik tempe "Mahkota" di Desa Prandon Kabupaten Ngawi.

2. Pembahasan Uji Fisher

Untuk uji fisher diperoleh nilai $\mathrm{F}_{\text {hitung }}$ adalah 6,693 sedangkan $F_{\text {tabel }}$ sebesar 4,043, di lain pihak besarnya $\mathrm{Sig}_{\text {hit }}$ adalah 0,003 sedangkan $\operatorname{Sig}_{\text {prob }} 0,05$. Hal ini berarti bahwa nilai $\mathrm{F}_{\text {hitung }} \geq \mathrm{F}_{\text {tabel }}(6,693 \geq 4,043)$ atau $\operatorname{Sig}_{\text {hit }} \leq \operatorname{Sig}_{\text {prob }}(0,003 \leq 0,05)$. Dengan ini berarti $\mathrm{H}_{0}$ ditolak, artinya ada pengaruh kualitas produk dan harga terhadap minat konsumen pada industri kripik tempe "Mahkota" di Desa Prandon Kabupaten Ngawi.

3. Pembahasan Ujit

Dapat dilihat pada hasil persamaan regresi 
$\mathrm{Y}=14,271+0,401 \mathrm{X}_{1}+0,196 \mathrm{X}_{2}$. Analisis tersebut dapat dijelaskan sebagai berikut :

$a=14,271$, artinya apabila variabel kualitas produk dan harga sama dengan nol sehingga minat konsumen tersebut sebesar 14,271.

$\mathrm{b}_{1}=0,401$ artinya nilai 0,401 merupakan koofisien regresi yang menunjukkan bahwa setiap upaya penambahan sebesar satu poin di kualitas produk akan ada kenaikan minat konsumen sebesar 0,401 .

$\mathrm{b}_{2}=0,196$ artinya nilai 0,196 merupakan koofisien regresi yang menunjukkan bahwa setiap upaya penambahan sebesar satu poin di harga akan ada kenaikan minat konsumen sebesar 0,196.

Sedangkan untuk uji t diperoleh nilai $\mathrm{t}_{\text {hitung }}$ adalah 3,195 sedangkan $\mathrm{t}_{\text {tabel }}$ sebesar 1,677, di lain pihak nilai Sig $_{\text {hit }}$ adalah 0,002 sedangkan $\operatorname{Sig}_{\text {prob }}$ 0,05. Hal ini berarti bahwa nilai $\mathrm{t}_{\text {hitung }} \geq \mathrm{t}_{\text {tabel }}(3,195 \geq 1,677)$ atau $\operatorname{Sig}_{\text {hit }} \leq$ $\operatorname{Sig}_{\text {prob }}(0,002 \leq 0,05)$. Dengan hal ini $\mathrm{H}_{0}$ ditolak, artinya ada beda pengaruh kualitas produk terhadap minat konsumen pada industri kripik tempe "Mahkota" di Desa Prandon Kabupaten Ngawi.

Selain itu dapat dilihat dari data di atas dapat diketahui variabel harga mempunyai nilai $t_{\text {hitung }}$ adalah 1,631 sedangkan $t_{\text {tabel }}$ sebesar 1,677, di lain pihak nilai Sig $_{\text {hit }}$ adalah 0,110 sedangkan Sigprob 0,05. Hal ini berarti bahwa nilai $\mathrm{t}_{\text {hitung }} \leq \mathrm{t}_{\text {tabel }}(1,631 \leq 1,677)$ atau $\operatorname{Sig}_{\text {hit }} \geq \operatorname{Sig}_{\text {prob }}(0,110 \geq 0,05)$. Dengan hal ini terima $\mathrm{H}_{0}$ artinya tidak ada beda pengaruh harga terhadap minat konsumen pada industri kripik tempe "Mahkota" di Desa Prandon Kabupaten Ngawi.

\section{PENUTUP}

\section{Simpulan}

Kualitas produk pada industri kripik tempe "Mahkota" di Desa Prandon Kabupaten Ngawi, dikatakan baik, hal ini dapat dilihat dari hasil statistik deskriptif dengan jumlah (N) sebanyak 50 responden mempunyai data sebagai berikut : (a) jumlah skor total sebesar 1827; (b) nilai rata-rata hitung (mean) sebesar 36,54; (c) median sebesar 36,00; (d) modus sebesar 36; (e) standar deviasi sebesar 3,092,486; (f) nilai minimum sebesar 28; (g) nilai maximum sebesar 43 .

Harga yang ada pada industri kripik tempe "Mahkota" di Desa Prandon Kabupaten Ngawi dikatakan baik, hal ini dapat dilihat dari hasil statistik deskritif dengan jumlah $(\mathrm{N})$ sebanyak 50 mempunyai data sebagai berikut: (a) jumlah skor total sebesar 1815; (b) nilai rata-rata hitung (mean) sebesar 36,30; (c) median sebesar 36,00; (d) modus sebesar 36; (e) standar deviasi sebesar 3,221; (f) nilai minimum sebesar 27; (g) nilai maximum sebesar 42 .

Minat konsumen dalam industri kripik tempe "Mahkota" di Desa Prandon Kabupaten Ngawi dikatakan baik, hal ini dapat dilihat dari hasil statistik deskriptif dengan jumlah (N) sebanyak 50 mempunyai deskripsi data adalah sebagai berikut: (a) jumlah skor total sebesar 1803; (b) nilai ratarata hitung (mean) sebesar 36,06; (c) median sebesar 36,50; (d) modus sebesar 37; (e) standar deviasi sebesar 3,013; (f) nilai minimum sebesar 27; (g) nilai maximum sebesar 42. (a) jumlah skor total sebesar 1803; (b) nilai rata-rata hitung (mean) sebesar 36,06; (c) median sebesar 36,50; (d) modus sebesar 37; (e) standar deviasi sebesar 3,013; (f) nilai minimum sebesar 27; (g) nilai maximum sebesar 42 .

Kualitas produk dan harga mempunyai pengaruh terhadap minat konsumen pada industri kripik tempe "Mahkota" di Desa Prandon Kabupaten Ngawi. Berdasarkan penelitian diperoleh hasil analisis regresi yang memuat uji korelasi, uji F, dan uji t.

\section{Saran}

\section{Bagi industri kripik tempe}

Kualitas produk yang baik dan harga yang sesuai berpengaruh terhadap minat 
konsumen untuk membeli produk kripik tempe, karena dengan kualitas produk kripik tempe yang bagus dan harganya sesuai dengan kualitasnya sehingga konsumen ingin membeli produk kripik tempe. Sehingga industri kripik tempe bisa terus meningkatkan kualitas produk dan harga yang sesuai dengan keninginan konsumen. Dengan meningkatkan dan pemilihan bahan baku kedelai yang berkualitas, harganya juga terjangkau oleh konsumen. Sehingga akan menghasilkan produk kripik tempe yang berkualitas juga.

\section{Bagi peneliti mendatang}

Bagi peneliti yang akan datang sebaiknya dapat mengembangkan variabel menambah atau mencari variabel lain selain kualitas produk dan harga karena masih banyak faktor lain yang mempengaruhi minat konsumen.

\section{DAFTAR PUSTAKA}

Basu Swasta dan Irawan. 2005. Manajemen Pemasaran Modern. Yogyakarta: Liberty Yogyakarta.

Basu Swasta. 2002. Azas-azas Marketing. Yogyakarta: Liberty Yogyakarta.

Cris person dengan alamat : http://jurnalsdm. blogspot.com/2011/10/memban un-minat-beli-definisi-faktor.html

Dorethea Wahyu Ariani dan Dr. Mohammad Ali. 2003. Manajemen Kualitas Pendekatan Sisi Kualitatif. Jakarta: Ghalia Indonesia.

Fandy Tjiptono dan Anastasia Dian. 2000. Total Quality Manajement. Yogyakarta: Andi Yogyakarta.

Freddy Rangkut. 2009. Strategi Promosi yang Kreatif dan Analisis Kasus Integrated Marketing Communication. Jakarta: PT. Gramedia Pustaka Utama.

H. Hadari Nawawi. 2005. Metode Penelitian Bidang Sosial. Yogyakarta: Gadjah Mada University Press.
Husein Umar. 2000. Riset Pemasaran dan Perilaku Konsumen. Jakarta: PT. Gramedia Pustaka Utama.

Iqbal Hasan. 2004. Analisis Data Penelitian dengan Statistik. Jakarta: PT. Bumi Aksara.

Juliansyah Noor. 2011. Metode Penelitian: Skripsi, Tesis, Desertasi, dan Karya Ilmiah. Jakarta: Prenada Media Group.

M. Mursid. 2010. Manajemen Pemasaran. Jakarta: Bumi Aksara.

M.N. Nasution. 2001. Manajemen Mutu Terpadu (Total Quality Management). Jakarta: Ghalia Indonesia.

Moehar Dhanil. 2003. Metode Penelitian Sosial Ekonomi. Jakarta: PT. Bumi Aksara.

Nasution S. 2004. Metodologi Research Penelitian Ilmiah. Jakarta: PT. Bumi Aksara.

Nugroho J. Setiadi. 2003. Perilaku Konsumen Konsep dan Implikasi untuk Strategi dan Penelitian Pemasaran. Jakarta: Prenada Media.

Philip Kotler dan Gary Armstrong. 2008. Prinsip-Prinsip Pemasaran. Jakarta: Erlangga.

Philip Kotler dan Nancy Lee. 2007. Pemasaran di Sektor Publik. Jakarta: PT. Macanan Jaya Cemerlang.

Sugiyono. 2010. Metode Penelitian Pendidikan Pendekatan KuantitatifKualitatif dan $R \& D$. Bandung: Alfabeta.

Suharsimi Arikunto. 2009. Manajemen Penelitian. Jakarta: Rineka Cipta.

Suharsimi Arikunto. 2010. Prosedur Penelitian. Jakarta: Rineka Cipta.

Thamrin Abdullah dan Dr. Francis Tantri. 2012. Manajemen Pemasaran. Jakarta: PT. Raja Grafindo Persada.

Zulian Yamith. 2005. Manajemen Kualitas Produk dan Jasa. Yogyakarta: Ekonomia. 